\title{
Studi Estimasi Kapasitas Pembebanan Transformator Berdasarkan Produk Domestik Regional Bruto (PDRB) Menggunakan Metode Regresi Linier di Gardu Induk Buduran Kabupaten Sidoarjo
}

\author{
${ }^{1}$ Nanda Rizki, 2 Yuni Rahmawati \& ${ }^{3}$ Dwi Prihanto \\ 1Jurusan Teknik Elektro \\ 2Universitas Negeri Malang \\ 1nandarizki593@gmail.com, 2yuni.rahmawati.ft@um.ac.id, 3dwiprihanto0524@gmail.com
}

\begin{abstract}
Abstrak
Kebutuhan daya di Kabupaten Sidoarjo dalam 5 tahun terakhir, mengalami kenaikan sebesar 33,08 \% setiap tahunnya. Gardu Induk (GI) Buduran merupakan sub sistem dari sistem transmisi tenaga listrik di Kabupaten Sidoarjo Semakin bertambahnya permintaan konsumsi listrik Kabupaten Sidoarjo maka semakin besar pula pembebanan daya yang ditanggung oleh transformator Gardu Induk (GI) Buduran. Oleh karena itu, diperlukan suatu metode estimasi kapasitas pembebanan transformator untuk mengantisipasi overload pada transformator dan menjaga kualitas distribusi listrik di Kabupaten Sidioarjo. Pada penelitian ini untuk mengetahui kapasitas pembebanan transformator dilakukan estimasi beban per-golongan pelanggan (rumah tangga, industri, bisnis, sosial, dan publik) dengan variabel yang mempengaruhi merupakan sektor perekoniomian pada data produk domestik regional bruto (PDRB). Selanjutnya, hasil estimasi tersebut akan dihubungkan dengan estimasi beban pada masing-masing transformator yang mensuplai jenis pergolongan pelanggan tersebut. Metode yang digunakan adalah metode regresi linier. Hasil estimasi dari penelitian ini, transformator II overload pada tahun 2022 dengan beban mencapai 49,0 MVA (82\%) dari kapasitas terpasang, transformator III overload pada tahun 2026 dengan beban mencapai 49,3 MVA (82\%) dari kapasitas terpasang, transformator IV overload pada tahun 2021 dengan beban mencapai 46,9 (80\%) dari kapasitas terpasang, dan transformator $\mathrm{V}$ overload pada tahun 2027 dengan beban mencapai 16,1 MVA (80\%) dari kapasitas terpasang.
\end{abstract}

Kata Kunci: estimasi, kapasitas, regresi linier, overload

\section{Pendahuluan}

Kebutuhan daya di Kabupaten Sidoarjo dalam 5 tahun terakhir, mengalami kenaikan sebesar 33,08 \% setiap tahunnya. Besarnya jumlah Produk Domestik Regional Bruto (PDRB) perkapital menurut lapangan usaha atas dasar harga berlaku 2010 s.d 2016, dari setiap tahun mengalami peningkatan dan terbesar dari sektor industri pengolahan [1], membuat konsumsi tenaga listrik yang disebabkan oleh PDRB meningkat, dimana terdapat asumsi bahwa ada hubungan antara kebutuhan energi listrik industri dengan produk domestik regional bruto [2]-[3].

Gardu Induk (GI) Buduran merupakan sub sistem dari sistem transmisi tenaga listrik di Kabupaten Sidoarjo Semakin bertambahnya permintaan konsumsi listrik Kabupaten Sidoarjo maka semakin besar pula pembebanan daya yang ditanggung oleh transformator Gl Buduran. Sedangkan pembebanan transformator tidak boleh melebihi 80\% dari kapasitas terpasang [4]-[5]. Oleh karena itu, diperlukan suatu metode estimasi kapasitas pembebanan transformator untuk mengantisipasi overload pada transformator dan menjaga kualitas distribusi listrik di Kabupaten Sidioarjo.

Estimasi kapasitas pembebanan trasformator dapat dilakukan mengunakan metode regresi linier [6]-[7]. Metode regresi linier terdapat hubungan antara variabel dipendent dan independent [8]. berdasarkan studi kasus pada penelitian ini dilakukan estimasi beban per-golongan pelanggan (rumah tangga, industri, bisnis, sosial, dan publik) dengan variabel independent merupakan sektor perekoniomian pada data PDRB. Selanjutnya, hasil estimasi tersebut akan dihubungkan dengan estimasi beban pada masing-masing transformator yang mensuplai jenis per-golongan pelanggan tersebut.

\section{Diskusi}

Pada bab diskusi dijelaskan prihal metode penelitian yang digunakan. Selain itu pada bab ini juga dijabarkan hasil penelitian yang didapatkan.

\subsection{Metode Penelitian}

Penelitian ini dibagi menjadi dua bagian. Bagian-bagian pada pada analisis data antara lain yaitu (1) peramalan beban, dan (2) menghitung kapasitas pembebanan trasformator. Gambar 1 menunjukan alur proses anaisis data pada peneitian ini. 


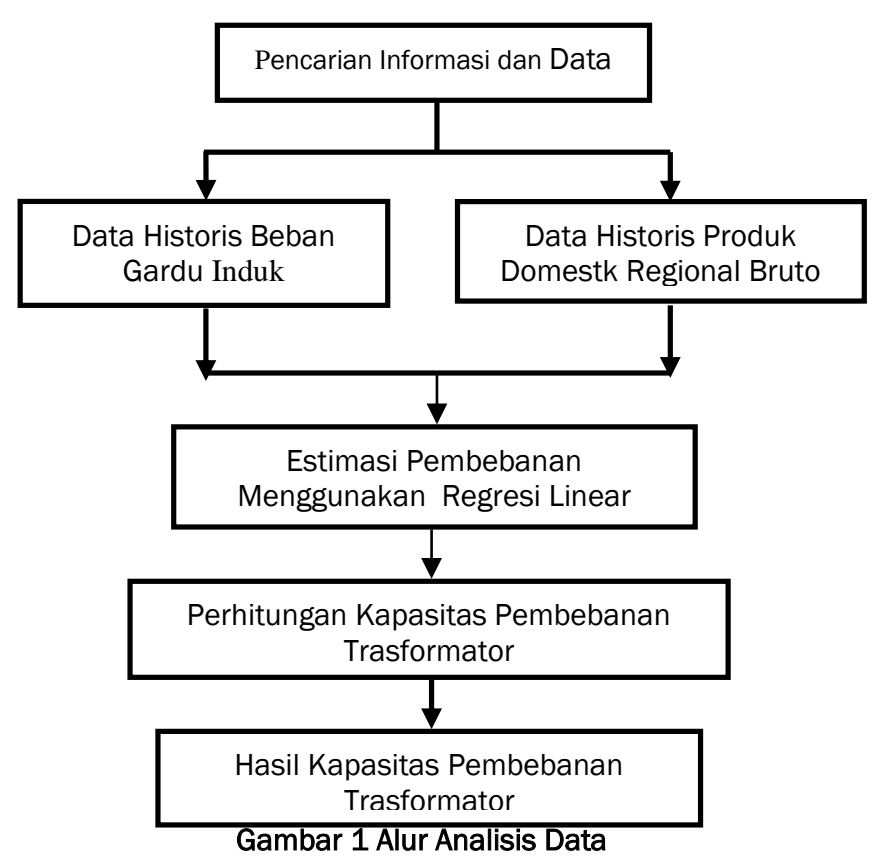

Analisis data dimulai dengan proses estimasi beban melalui data historis beban GI Buduran yang diperoleh dari PLN dan PDRB yang diperoleh dari BPS Kabupaten Sidorjo. Data yang digunakan adalah data beban GI dan data PDRB yang akan diolah mengunakan metode regresi linier. Hasil estimasi pembebanan tersebut digunakan untuk menghitung kapasitas pembebanan trasformator, selanjutnya dilakukan analisis kapasitas pembebanan trasformator menurut standart SPLN 17:1979.

Data yang digunakan akan diuji terlebih dahulu korelasi antara variabel dipendend dan independend, menggunakan perhitungan pearson product moment $(r)$ [9]

$\mathrm{r}=\frac{\mathrm{n} \cdot \Sigma \mathrm{xy}-(\Sigma \mathrm{x}) \cdot(\Sigma \mathrm{y})}{\sqrt{\left\{\mathrm{n} \Sigma \mathrm{x}^{2}-(\Sigma \mathrm{x})^{2}\right\} \cdot\left\{\mathrm{n} \Sigma \mathrm{y}^{2}-(\Sigma \mathrm{y})^{2}\right\}}}$

Representasi dari hasil pearson product moment ( $r$ ) dapat menunjukkan tingkat korelasi antar variabel. Tingkat korelasi tersebut dapat dilihat pada Tabel 1 [10]

Tabel 1 Tabel tingkat korelasi pearson product moment

\begin{tabular}{|c|c|}
\hline Nilai $\mathbf{r}$ & Tingkat korelasi \\
\hline 0 & Tidak ada korelasi \\
\hline $0,01-0,25$ & Korelasi sangat lemah \\
\hline $0,26-0,50$ & Korelasi cukup \\
\hline $0,51-0,75$ & Korelasi kuat \\
\hline $0,76-0,99$ & Korelasi sangat kuat \\
\hline 1 & Korelasi sempurna \\
\hline
\end{tabular}

Prakiraan estimasi pembebanan dilakukan dengan menggunakan metode regresi linier, Persamaan 2 dan 3 adalah perhitungan matematis dari regresi linier [11] $y=a+b x$

Berdasarkan persamaan 2, y merupakan variabel tidak bebas, $x$ merupakan variabel bebas, a merupakan konstanta, dan b merupakan koefisien.

$y=a+b_{1} X_{1}+b_{2}+\ldots \ldots \ldots b_{k} X_{k}$

Berdasarkan persamaan 3, y merupakan variabel tidak bebas. $X$ merupakan variabel bebas dengan rincian $x_{1}, x_{2}, x_{3}, x_{k}$ merupakan variabel bebas 1, 2, 3 dan variabel bebas ke-k. Simbol a merupakan konstanta, dan b merupakan koefisien.

Evaluasi hasil estimasi beban mengunakan Mean Absolute Percentage Error (MAPE). Persamaan 4 merupakan rumus matematis MAPE [12-[13].

MAPE $=\frac{\left|\grave{y}_{t}-\grave{y}_{t-1}\right|}{\grave{y}_{t-1}} \times 100 \%$

$\grave{y}_{t}$ adalah hasil prakiraan suatu variabel pada periode $\mathrm{t}$, sedangkan $\grave{y}_{t-1}$ adalah hasil prakiraan sebelum periode t. Tabel 2 menunjukan pengelompokan tingkat akurasi berdasarkan MAPE.[14]

Table 2 Prosentase MAPE dan Akurasi Prakiraan

\begin{tabular}{|c|c|}
\hline Variabel & Akurasi Prakiran \\
\hline MAPE $\leq 10 \%$ & Tinggi \\
\hline $10 \%<$ MAPE $\leq 20 \%$ & Baik \\
\hline $20 \%<$ MAPE $\leq 50 \%$ & Reasonable \\
\hline MAPE $>50 \%$ & Rendah \\
\hline
\end{tabular}

Penentuan batas kapasitas pemebebanan di hitung mengunkan perhitungan persentase pembebanan, persamaan 5 merupakan rumus matematis persentase pembebanan [15].

$\%$ pembebanan $=\frac{s_{t}}{K_{\text {trasformator }}} \times 100 \%$

Berdasarkan persamaan $5, S_{t}$ merupakan pembebanan transformator sudah terpakai selama beropasi (MVA). Sedangkan $K_{\text {trasformator }}$ merupakan kapasitas transformator yang terpasang (MVA).

\subsection{Hasil dan Pembahasan}

Pada sub bab hasil dan pembahasan akan ditampilkan hasil dari penelitian yang dilakukan. Berdasarkan hasil penelitian, selanjutnya dilakukan analisis.

\subsubsection{Hasil Korelasi Beban Golongan Pelanggan dengan PDRB}

Perhitungan korelasi pada penelitian ini mengunakan pearson product moment ( $r$ ) mengunakan software spss, Pada penelitian ini masing-masing baban golongan pelanggan akan dikorelasikan dengan sektor perekonomian yang di asumsikan berhubungan dengan beban golongan pelanggan berikut hasil korelasi mengunakan software spss : 
Seminar Nasional Instrumentasi, Kontrol dan Otomasi (SNIKO) 2018 Bandung, Indonesia, 10-11 Desember 2018

Tabel 3 Pengujian Korelasi Daya RT dengan PDRB

\begin{tabular}{llllll}
\hline \multicolumn{7}{c}{ Correlation } \\
\hline Daya & Person & $(\mathrm{X} 1)$ & $(\mathrm{X} 2)$ & $(\mathrm{X} 3)$ & $(\mathrm{X} 4)$ \\
\cline { 3 - 6 } $\begin{array}{l}\text { Rumah } \\
\text { Tangga }\end{array}$ & $\begin{array}{l}\text { corelation } \\
\text { Sig }(2-\end{array}$ &, $985^{\prime \prime}$ &, $992^{\prime \prime}$ &, $998^{\prime \prime}$ &, $992^{\prime \prime}$ \\
& tailed $)$ &, 000 &, 000 &, 000 &, 000 \\
\hline
\end{tabular}

Berdasarkan Tabel 3, nilai person corelation variabel real estate (X1), penguluaran konsumsi Rumah Tangga (X2), pengeluaran LPNRT (X3), dan perubahan inventori (X4). dengan daya rumah tangga (Y) pada rentan 0,76 - 0,99 dan nilai signifikasi yang didapat adalah $0,000<0,005$ yang berarti terdapat korelasi sangat kuat, dan korelasi siginifikan antara masing-masing variabel.

Tabel 4 Pengujian Korelasi Daya Industri dengan PDRB Correlation

\begin{tabular}{llcc}
\hline \multicolumn{3}{c}{ Correlation } \\
\cline { 2 - 3 } Daya & Person & $(\mathrm{X} 1)$ & $(\mathrm{X} 2)$ \\
\cline { 3 - 4 } Industri & corelation &, $985^{\prime \prime}$ &, 936 \\
Y) & Sig (2-tailed) &, 000 &, 000 \\
\hline
\end{tabular}

Berdasarkan Tabel 4 nilai person corelation variabel Industri Pengolahan (X1), dan Pertambangan dan Penggalian (X2) dengan daya industri $(Y)$ pada rentan 0,76 - 0,99 dan nilai signifikasi yang didapat adalah 0,000 < 0,005 yang berarti terdapat korelasi sangat kuat, dan korelasi siginifikan antara masing-masing variabel.

Tabel 5 pengujian Korelasi Daya Bisnis dengan PDRB

\begin{tabular}{|c|c|c|c|c|c|c|}
\hline \multicolumn{7}{|c|}{ Correlation } \\
\hline \multirow{3}{*}{$\begin{array}{l}\text { Daya } \\
\text { Bisnis } \\
\text { (Y) }\end{array}$} & Person & $\begin{array}{ll}\mathrm{X} 1) & (\mathrm{X} 2) \\
\end{array}$ & $(\mathrm{X} 3)$ & (X4) & (X5) & $(X 6)$ \\
\hline & corelation & ,861 & ,996 & ,991 & ,983 & ,987 \\
\hline & $\begin{array}{l}\text { Sig (2- } \\
\text { tailed) }\end{array}$ & ,000 & 000, & 000, & 000, & ,000 \\
\hline
\end{tabular}

Berdasarkan Tabel 5 nilai person corelation variabel konstruksi (X1), pengadaan Listrik dan Gas (X2), perdagangan besar dan eceran reparasi mobil dan sepeda (X3), pertanian kehutanan dan perikanan (X4), jasa perusahaan (X5), dan pengadaan air pengololaan sampah limbah dan daur Ulang (X6). dengan daya bisnis $(\mathrm{Y})$ pada rentan 0,76 - 0,99, dan nilai signifikasi yang didapat adalah $0,000<0,005$ yang berarti terdapat korelasi sangat kuat, dan korelasi siginifikan antara masing-masing variabel.

Tabel 6 Pengujian Korelasi Daya Sosial dengan PDRB

\begin{tabular}{|c|c|c|c|c|c|c|}
\hline \multicolumn{7}{|c|}{ Correlation } \\
\hline \multirow{3}{*}{$\begin{array}{l}\text { Daya } \\
\text { Sosial } \\
\text { (Y) }\end{array}$} & Person & $\begin{array}{ll}\mathrm{X} 1) & (\mathrm{X} 2) \\
\end{array}$ & (X3) & (X4) & (X5) & $(\mathrm{X} 6)$ \\
\hline & corelation & 945, 979, & ,995 & 991 & ,992 & ,992 \\
\hline & $\begin{array}{l}\text { Sig (2- } \\
\text { tailed) }\end{array}$ & 000, 000, & ,000 & ,000 & ,000 & ,000 \\
\hline
\end{tabular}

variabel akomodasi makan dan minum (X1), admin pemerintah pertanahan dan jasmos (X2), jasa keuangan dan asuransi (X3), jasa pendidikan (X4), jasa kesehatan dan kegiatan sosial (X5), dan jasa lainnya (X6). dengan daya sosial $(Y)$ pada rentan 0,76 - 0,99 dan nilai signifikasi yang didapat adalah $0,000<0,005$ yang berarti terdapat korelasi sangat kuat, dan korelasi siginifikan antara masing-masing variabel.
Tabel 7 Pengujian Korelasi Daya Publik dengan PDRB

\begin{tabular}{llcc}
\hline \multicolumn{4}{c}{ Correlation } \\
\hline Daya & Person & $(\mathrm{X} 1)$ & $(\mathrm{X} 2)$ \\
\cline { 3 - 4 } Industri & corelation &, $978^{\prime \prime}$ &, $992^{\prime \prime}$ \\
(Y) & Sig (2-tailed) &, 000 &, 000 \\
\hline
\end{tabular}

Berdasarkan Tabel 7 nilai person corelation variabel transportasi dan pergudangan (X1), dan informasi dan komunikasi (X2) dengan daya publik (Y) pada rentan 0,76 - 0,99 dan nilai signifikasi yang didapat adalah 0,000 $<0,005$ yang berarti terdapat korelasi sangat kuat, dan korelasi siginifikan antara masing-masing variabel.

\subsubsection{Hasil Estimasi beban golongan Pelanggan berdasarkan PDRB}

Estimasi beban golongan pelanggan berdasarkan PDRB dibagi menjadi 5 jenis golongan pelanggan, dimana Pertumbuhan daya pergolongan pelanggan menjadi variabel dipendent $(\mathrm{Y})$, yang dipengaruh oleh unit perekonomian PDRB sebagai variabel independend $(\mathrm{X})$. Perhitungan beban per-golongan pelanggan berdasarkan PDRB dibagi menjadi 5 jenis, yaitu (a) estimasi pertumbuhan daya pelanggan rumah tangga, (b) estimasi pertumbuhan daya pelanggan industri, (c) estimasi pertumbuhan daya pelanggan bisnis, (d) estimasi pertumbuhan daya pelanggan sosial, dan (e) perhitungan pertumbuhan daya pelanggan publik.

\section{a. Estimasi Pertumbuhan Daya Pelanggan Rumah}

Berdasarkan penyusunan model persamaan regresi linier berganda maka didapat model persamaan untuk estimasi daya rumah tangga sebagai berikut :

$$
\begin{aligned}
& Y=-159119722-131,79 X_{1}+51,90 X_{2}+72,56 X_{3}- \\
& 415,96 X_{4}
\end{aligned}
$$

Berdasarkan persamaan 5, Y merupakan daya rumah tangga (VA). $X$ merupakan variabel bebas (Rupiah) dengan $\mathrm{X}_{1}, \mathrm{X}_{2}, \mathrm{X}_{3}, \mathrm{X}_{4}$ berturur-turut yaitu nilai Real Estate tahun ke-t, nilai konsumsi rumah tangga tahun ke-t, pengeruaran LNPRT tahun ke-t, dan perubahan inventori tahun ke-t.

Berdasarkan persamaan 5 didapat hasil pertumbuhan daya sebagai berikut:

Tabel 8 Hasil Estimasi Daya Industri 2017 s.d 2027
\begin{tabular}{|c|c|}
\hline Tahun & Daya rumah tangga (VA) \\
\hline 2017 & 200931374,8 \\
\hline 2018 & 214519350,1 \\
\hline 2019 & 228107325,4 \\
\hline 2020 & 241695300,7 \\
\hline 2021 & 255283276,0 \\
\hline 2022 & 268871251,3 \\
\hline 2023 & 282459226,6 \\
\hline 2024 & 296047201,9 \\
\hline 2025 & 309635177,2 \\
\hline 2026 & 323223152,5 \\
\hline 2027 & 336811127,8 \\
\hline Persentase Kenaikan & $67,62 \%$ \\
\hline
\end{tabular}




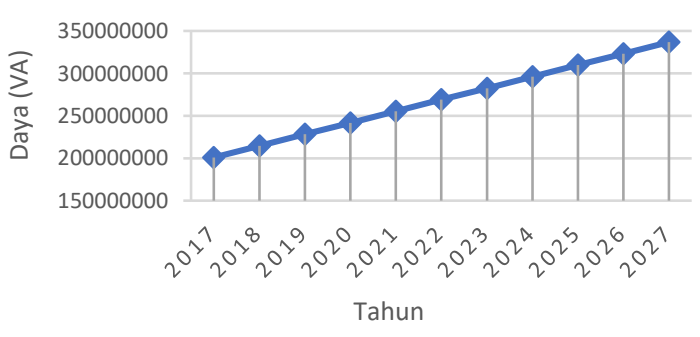

Gambar 2 Grafik Pertumbuhan Beban Golongan Rumah Tangga GI Buduran Tahun 2017 s.d 2027

Berdasarkan Tabel 5 dan Gambar 2 dilihat bahwa pertumbuhan daya yang dipengaruhi unit PDRB golongan rumah tangga pada tahun 2017 s.d 2027 mengalami peningkatan sebesar $67,62 \%$.

\section{b. Estimasi Pertumbuhan Daya Pelanggan Industri}

Berdasarkan penyusunan model persamaan regresi linier berganda maka didapat model persamaan untuk estimasi daya industri yaitu:

$Y=-524385229,87+5,56 X_{1}-8,075 X_{2}$

Berdasarkan persamaan $6, Y$ merupakan daya industria (VA). $X$ merupakan variabel bebas (Rupiah) dengan $X_{1}, \quad X_{2}$ berturur-turut yaitu nilai industri pengolahan tahun ke-t, dan nilai pertambangan dan penggalian ke-t.

Berdasarkan persamaan 6 didapat hasil pertumbuhan daya sebagai berikut:

Tabel 9 Hasil Estimasi Daya Industri 2017 s.d 2027

\begin{tabular}{|c|c|}
\hline Tahun & Daya Industri (VA) \\
\hline 2017 & 292232973,3 \\
\hline 2018 & 309164205,9 \\
\hline 2019 & 326095438,5 \\
\hline 2020 & 343026671,1 \\
\hline 2021 & 359957903,8 \\
\hline 2022 & 376889136,4 \\
\hline 2023 & 393820369 \\
\hline 2024 & 410751601,6 \\
\hline 2025 & 427682834,2 \\
\hline 2026 & 444614066,8 \\
\hline 2027 & 461545299,5 \\
\hline Persentase Kenaikan & $57,94 \%$ \\
\hline
\end{tabular}

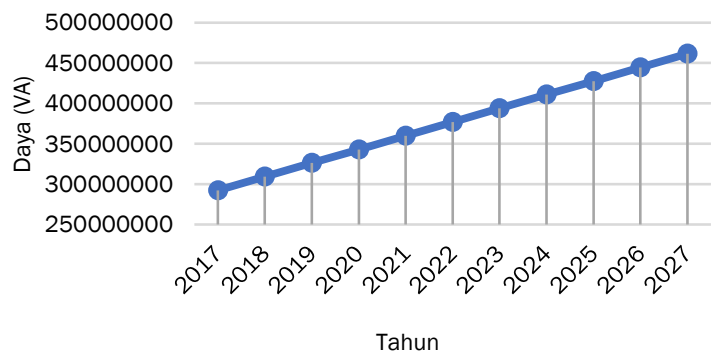

Gambar 3 Grafik Pertumbuhan Beban Golongan Industri GI Buduran Tahun 2017 s.d 2027

Berdasarkan Tabel 9 dan Gambar 3 dilihat bahwa pertumbuhan daya yang dipengaruhi unit PDRB golongan Industri pada tahun 2017 s.d 2027 mengalami peningkatan sebesar 57,94\%.

\section{c. Estimasi Pertumbuhan Daya Pelanggan Bisnis,}

Berdasarkan penyusunan model persamaan regresi linier berganda maka didapat model persamaan untuk estimasi daya bisnis sebagai berikut:

$Y=32713986.74-60.25 X_{1}+18,81 X_{2}+31,17 X_{3}-$
$70.19 X_{4}+1417,67 X_{5}-6,063 \times 10^{-13} X_{6}$

Berdasarkan persamaan 7, Y merupakan daya bisnis (VA). $X$ merupakan variabel bebas (Rupiah) dengan $X_{1}, X_{2}, X_{3}, X_{4}, X_{5}, X_{6}$ berturur-turut yaitu nilai Konstruksi tahun ke-t, nilai pengadaan listrik dan gas tahun ke-t, nilai perdagangan besar dan eceran tahun ke-t, nilai pertanian kehutanan dan perikanan tahun ke-t, nilai jasa perusahaan tahun ke-t, dan nilai pengadaan air pengolahan sampah dan daur ulang tahun ke-t.

Berdasarkan persamaan 7 didapat hasil pertumbuhan daya sebagai berikut:

Tabel 10 Hasil Estimasi Daya Bisnis 2017 s.d 2027

\begin{tabular}{|c|c|}
\hline Tahun & Daya Bisnis (VA) \\
\hline 2017 & 91692705,33 \\
\hline 2018 & 98760603,05 \\
\hline 2019 & 105828500,8 \\
\hline 2020 & 112896398,5 \\
\hline 2021 & 119964296,2 \\
\hline 2022 & 127032193,9 \\
\hline 2023 & 134100091,6 \\
\hline 2024 & 141167989,3 \\
\hline 2025 & 148235887 \\
\hline 2026 & 155303784,8 \\
\hline 2027 & 162371682,5 \\
\hline Persentase Kenaikan & $77,08 \%$ \\
\hline
\end{tabular}

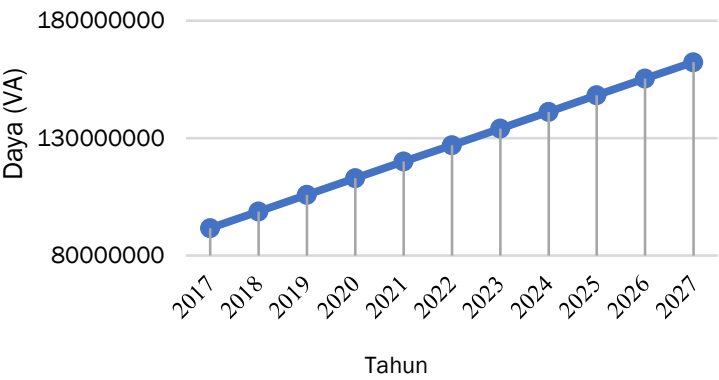

Gambar 4 Grafik Pertumbuhan Beban Golongan Bisnis GI Buduran Tahun 2017 s.d 2027

Berdasarkan Tabel 10 dan Gambar 4 dilihat bahwa pertumbuhan daya yang dipengaruhi unit PDRB golongan Bisnis pada tahun 2017 s.d 2027 mengalami peningkatan sebesar 77,08 \%.

\section{d. Estimasi Pertumbuhan Daya Pelanggan Sosial}

Berdasarkan penyusunan model persamaan regresi linier berganda maka didapat model persamaan untuk estimasi daya sosial sebagai berikut:

$$
\begin{gathered}
Y=259083628,2+90,44 X_{1}-141,97 X_{2}+297,52 X_{3}- \\
419,84 X_{4}-390,35 X_{5}+2,69 \times 10^{-12} X_{6}
\end{gathered}
$$


Berdasarkan persamaan 8, Y merupakan daya sosial (VA). $X$ merupakan variabel bebas (Rupiah) dengan $X_{1}, X_{2}, X_{3}, X_{4}, X_{5}, X_{6}$ berturur-turut yaitu nilai akomodasi makan dan minum tahun ke$\mathrm{t}$, nilai admin pemerintah pertanahan dan jasmos tahun ke-t, nilai jasa keuangan dan asuransi tahun ke-t, nilai jasa pendidikan tahun ke-t, nilai jasa kesehatan dan kegiatan sosial tahun ke-t, dan nilai jasa lainnya.

Berdasarkan persamaan 8 didapat hasil pertumbuhan daya sebagai berikut:

Tabel 11 Hasil Estimasi Daya Sosial 2017 s.d 2027

\begin{tabular}{|c|c|}
\hline Tahun & Daya Sosial (VA) \\
\hline 2017 & 20524172 \\
\hline 2018 & 23017484 \\
\hline 2019 & 25510796 \\
\hline 2020 & 28004108 \\
\hline 2021 & 30497420 \\
\hline 2022 & 32990732 \\
\hline 2023 & 35484044 \\
\hline 2024 & 37977356 \\
\hline 2025 & 40470668 \\
\hline 2026 & 42963980 \\
\hline 2027 & 45457292 \\
\hline Persentase Kenaikan & $121,48 \%$ \\
\hline
\end{tabular}

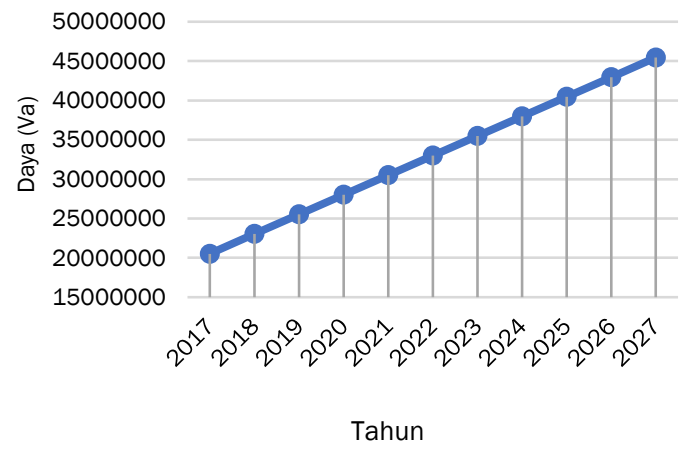

Gambar 5 Grafik Pertumbuhan Beban Golongan Sosial GI Buduran Tahun 2017 s.d 2027

Berdasarkan Tabel 11 dan Gambar 5 dilihat bahwa pertumbuhan daya yang dipengaruhi unit PDRB golongan sosial pada tahun 2017 s.d 2027 mengalami peningkatan sebesar $121,48 \%$.

\section{e. Estimasi Pertumbuhan Daya Pelanggan Publik}

Berdasarkan penyusunan model persamaan regresi linier berganda maka didapat model persamaan untuk estimasi daya publik yaitu:

$Y=-505534,26+0,19 X_{1}+1,67 X_{2}$

Berdasarkan persamaan 9, Y merupakan daya publik (VA). $X$ merupakan variabel bebas (Rupiah) dengan $X_{1}, X_{2}$ berturur-turut yaitu nilai Transportasi dan Pergudangan Tahun ke-t, dan nilai Informasi dan Komunikasi ke-t.

Berdasarkan persamaan 8 didapat hasil pertumbuhan daya sebagaimana ditunjukkan pada Tabel 12 dibawah ini:
Tabel 12 Hasil Estimasi Daya Publik 2017 s.d 2027

\begin{tabular}{|c|c|}
\hline Tahun & Daya Publik (VA) \\
\hline 2017 & 10617317 \\
\hline 2018 & 11294438 \\
\hline 2019 & 11971559 \\
\hline 2020 & 12648680 \\
\hline 2021 & 13325801 \\
\hline 2022 & 14002922 \\
\hline 2023 & 14680043 \\
\hline 2024 & 15357164 \\
\hline 2025 & 16034285 \\
\hline 2026 & 16711406 \\
\hline 2027 & 17388527 \\
\hline Persentase Kenaikan & $63,78 \%$ \\
\hline
\end{tabular}

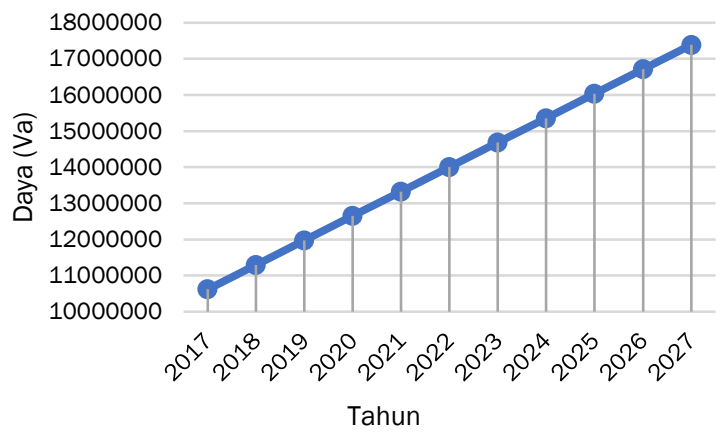

Gambar 6 Grafik Pertumbuhan Beban Golongan Publik GI Buduran Tahun 2017 s.d 2027

Berdasarkan Tabel 12 dan Gambar 6 dilihat bahwa pertumbuhan daya yang dipengaruhi unit PDRB golongan sosial pada tahun 2017 s.d 2027 mengalami peningkatan sebesar $121,48 \%$.

\subsubsection{Hasil Estimasi beban Tranformator}

Estimasi beban transformator didasarankan pada jenis golongan pelanggan yang disuplai transformator tersebut. Berikut hasil estimasi beban masing-masing transformator GI Buduran.

\section{a. Estimasi beban transformator II}

Berdasarkan penyusunan model persamaan regresi linier berganda maka didapat model persamaan untuk estimasi beban Transformator II sebagai berikut:

$$
Y=18,71-0,000000079 X_{1}+0,000000427 X_{2}+
$$$$
0,0000001749 X_{3}
$$

Berdasarkan persamaan 10, Y merupakan beban transformator II (MVA). X merupakan variabel bebas (VA) dengan $X_{1}, X_{2}, X_{3}$, berturur-turut yaitu daya industri tahun ke-t, daya bisnis tahun ke-t, daya sosial tahun ke-t.

Berdasarkan persamaan 10 didapat hasil pertumbuhan beban transformator II sebagaimana ditunjukkan pada Tabel 13 dibawah ini: 
Tabel 13 Hasil Estimasi Beban Trafo II 2017 s.d 2027

\begin{tabular}{|c|c|}
\hline Tahun & Beban Trafo II (MVA) \\
\hline 2017 & 38,4 \\
\hline 2018 & 40,5 \\
\hline 2019 & 42,6 \\
\hline 2020 & 44,8 \\
\hline 2021 & 46,9 \\
\hline 2022 & 49,0 \\
\hline 2023 & 51,1 \\
\hline 2024 & 53,2 \\
\hline 2025 & 55,4 \\
\hline 2026 & 57,5 \\
\hline 2027 & 59,6 \\
\hline Persentase Kenaikan & $\mathbf{5 5 , 2 1} \%$ \\
\hline
\end{tabular}

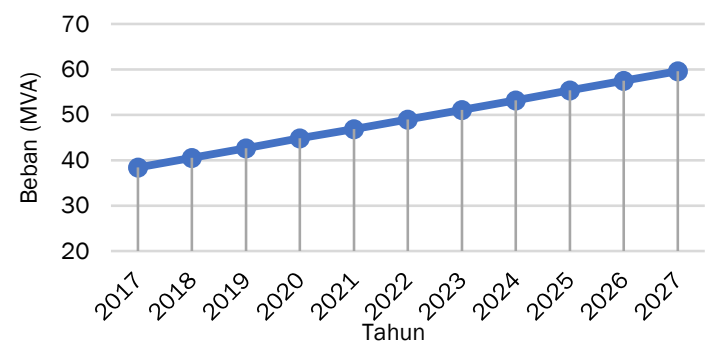

Gambar 7 Grafik Pertumbuhan Beban Transformator II Tahun 2017 s.d 2027

Berdasarkan Tabel 13 dan Gambar 7 dilihat bahwa pertumbuhan beban transformator II pada tahun 2017 s.d 2027 mengalami peningkatan $55,21 \%$ mengikuti pertumbuhan daya yang mempengaruhi transformator II pada tahun 2017 s.d 2017.

\section{b. Estimasi beban transformator III}

Berdasarkan penyusunan model persamaan regresi linier berganda maka didapat model persamaan untuk estimasi beban Transformator III sebagai berikut:

$$
Y=8,039983077+0,000000064 X_{1}+0,0000012 X_{2}
$$

Berdasarkan persamaan 11, Y merupakan beban transformator III (MVA). X merupakan variabel bebas (VA) dengan $X_{1}, X_{2}$, berturur-turut yaitu daya rumah tangga tahun ke-t, daya publik tahun ke-t, daya sosial tahun ke-t.

Berdasarkan persamaan 11 didapat hasil pertumbuhan beban transformator III berikut:

Tabel 14 Hasil Estimasi Beban Trafo III 2017 s.d 2027

\begin{tabular}{|c|c|}
\hline Tahun & Beban Trafo III (MVA) \\
\hline 2017 & 34,0 \\
\hline 2018 & 35,7 \\
\hline 2019 & 37,4 \\
\hline 2020 & 39,1 \\
\hline 2021 & 40,8 \\
\hline 2022 & 42,5 \\
\hline 2023 & 44,2 \\
\hline 2024 & 45,9 \\
\hline 2025 & 47,6 \\
\hline 2026 & 49,3 \\
\hline 2027 & 51,0 \\
\hline Persentase Kenaikan & $50 \%$ \\
\hline
\end{tabular}

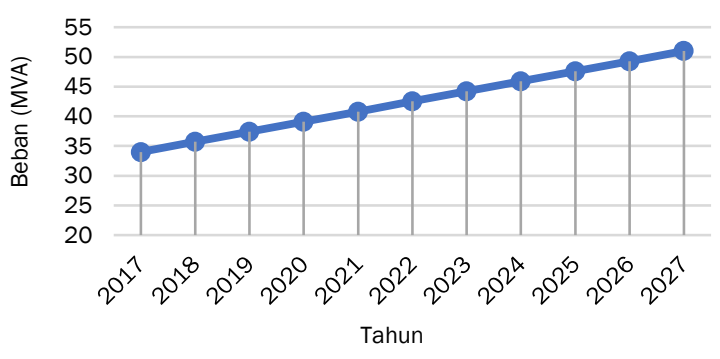

Gambar 8 Grafik Pertumbuhan Beban Transformator III Tahun 2017 s.d 2027

Berdasarkan Tabel 14 dan Gambar 8 dilihat bahwa pertumbuhan beban transformator III pada tahun 2017 s.d 2027 mengalami peningkatan 50 $\%$ mengikuti pertumbuhan daya yang mempengaruhi transformator III pada tahun 2017 s.d 2017.

\section{c. Estimasi beban transformator IV}

Berdasarkan penyusunan model persamaan regresi linier berganda maka didapat model persamaan untuk estimasi beban Transformator IV sebagai berikut:

$Y=10,28+0,00000015 X_{1} 10,28+0,00000015 X_{2}+$ $0,000000074 X_{3}$

Berdasarkan persamaan 12, Y merupakan beban transformator IV (MVA). X merupakan variabel bebas (VA) dengan $\mathrm{X}_{1}, \mathrm{X}_{2}, \mathrm{X}_{3}$, berturur-turut yaitu daya rumah tangga tahun ke-t, daya industri tahun ke-t, daya bisnis tahun ke-t.

Berdasarkan persamaan 12 didapat hasil pertumbuhan beban transformator IV sebagai berikut:

Tabel 15 Hasil Estimasi Beban Trafo IV 2017 s.d 2027
\begin{tabular}{|c|c|}
\hline Tahun & Beban Trafo IV (MVA) \\
\hline 2017 & 38,4 \\
\hline 2018 & 40,5 \\
\hline 2019 & 42,6 \\
\hline 2020 & 44,8 \\
\hline 2021 & 46,9 \\
\hline 2022 & 49,0 \\
\hline 2023 & 51,1 \\
\hline 2024 & 53,2 \\
\hline 2025 & 55,4 \\
\hline 2026 & 57,5 \\
\hline 2027 & 59,6 \\
\hline Persentase Kenaikan & $55,21 \%$ \\
\hline
\end{tabular}

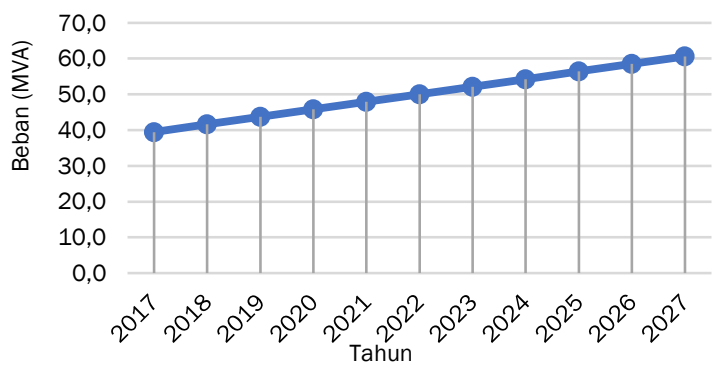

Gambar 9 Grafik Pertumbuhan Beban Transformator IV Tahun 2017 s.d 2027 
Berdasarkan Tabel 15 dan Gambar 9 dilihat bahwa pertumbuhan beban transformator IV pada tahun 2017 s.d 2027 mengalami peningkatan $55,21 \%$ mengikuti pertumbuhan daya yang mempengaruhi transformator III pada tahun 2017 s.d 2017.

\section{d. Estimasi beban transformator V}

Berdasarkan penyusunan model persamaan regresi linier berganda maka didapat model persamaan untuk estimasi beban Transformator $\mathrm{V}$ sebagai berikut:

$Y=-0,597031652-0,000000021 X_{1}+$ $0,000000051 X_{2}$.

Berdasarkan persamaan 13, Y merupakan beban transformator $\mathrm{V}$ (MVA). X merupakan variabel bebas (VA) dengan $X_{1}, X_{2}$, berturur-turut yaitu daya rumah tangga tahun ke-t, daya industri tahun ke-t, daya sosial tahun ke-t.

Berdasarkan persamaan 11 didapat hasil pertumbuhan beban transformator III sebagai berikut:

Tabel 15 Hasil Estimasi Beban Trafo V 2017 s.d 2027

\begin{tabular}{|c|c|}
\hline Tahun & Beban Trafo V (MVA) \\
\hline 2017 & 10,2 \\
\hline 2018 & 10,8 \\
\hline 2019 & 11,4 \\
\hline 2020 & 12,0 \\
\hline 2021 & 12,5 \\
\hline 2022 & 13,1 \\
\hline 2023 & 13,7 \\
\hline 2024 & 14,3 \\
\hline 2025 & 14,9 \\
\hline 2026 & 15,5 \\
\hline 2027 & 16,1 \\
\hline Persentase Kenaikan & $\mathbf{5 7 , 8 4} \%$ \\
\hline
\end{tabular}

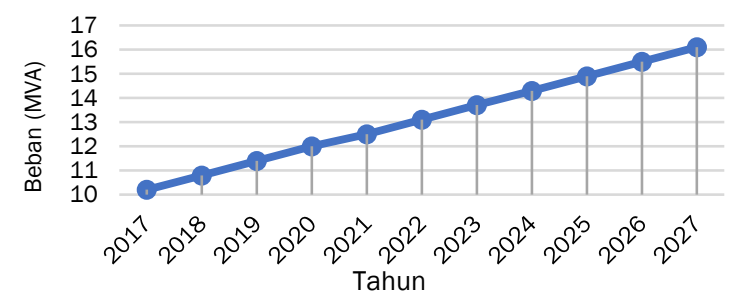

Gambar 9 Grafik Pertumbuhan Beban Transformator IV Tahun 2017 s.d 2027

Berdasarkan Tabel 15 dan Gambar 8 dilihat bahwa pertumbuhan beban transformator III pada tahun 2017 s.d 2027 mengalami peningkatan 50 $\%$ mengikuti pertumbuhan daya yang mempengaruhi transformator III pada tahun 2017 s.d 2017.

Setelah didapatkan hasil beban masing-masing transformator dilakukan evaluasi Hasil Akurasi Estimasi Beban Transformator mengunakan MAPE hasil evaluasi dapat dilihat pad tabel 16 sebagai berikut:
Tabel 16 Hasil Error MAPE Estimasi Beban Transformator GI Buduran

\begin{tabular}{|c|c|c|c|}
\hline Trafo & $\begin{array}{c}\text { Data Aktual } \\
\text { Beban Trafo } \\
\text { (MVA) }\end{array}$ & $\begin{array}{c}\text { Hasil Estimasi } \\
\text { Beban Trafo } \\
\text { (MVA) }\end{array}$ & $\begin{array}{c}\text { Error MAPE } \\
\text { (\%) }\end{array}$ \\
\hline II & 38,7 & 38,4 & 32 \\
\hline III & 34,2 & 34,0 & 24 \\
\hline IV & 39,7 & 39,5 & 23 \\
\hline V & 10,4 & 10,2 & 23 \\
\hline
\end{tabular}

Berdasarkan Tabel 16 Nilai error estimasi beban trasnformator II sebesar 32\%, Transformator III 24\%, Transformator IV $23 \%$, dan Transformator V 23\% nilai tersebut masih di kategorikan Reasonable (Layak).

\subsubsection{Hasil kapasitas transformator}

Perhitungan kapasitas pembenanan transformator dapat menggunakan persamaan 5 , pada penelitian ini pembebanan transformator didapat dari hasil peramalan beban transformator dibagi dengan kapasitas transformator, terpasang. Hasil Kapasitas pembebanan transformator dapat dilihat pada Tabel 17 sebagai berikut:

Tabel 17 Hasil Perhitungan Persentase Pembebanan Transformator GI Buduran Tahun 2017 s.d 2027

\begin{tabular}{|c|c|c|c|c|}
\hline \multirow{2}{*}{ Tahun } & \multicolumn{4}{|c|}{ Transformator } \\
\cline { 2 - 5 } & \multicolumn{4}{|c|}{ Persentase Pembebanan (\%) } \\
\cline { 2 - 5 } & II & III & IV & V \\
\hline 2017 & 64 & 57 & 66 & 51 \\
\hline 2018 & 68 & 59 & 69 & 54 \\
\hline 2019 & 71 & 62 & 73 & 57 \\
\hline 2020 & 75 & 65 & 76 & 60 \\
\hline 2021 & 78 & 68 & 80 & 63 \\
\hline 2022 & 82 & 71 & 83 & 66 \\
\hline 2023 & 85 & 74 & 87 & 69 \\
\hline 2024 & 89 & 76 & 90 & 72 \\
\hline 2025 & 92 & 79 & 94 & 74 \\
\hline 2026 & 96 & 82 & 97 & 77 \\
\hline 2027 & 99 & 85 & 101 & 80 \\
\hline
\end{tabular}

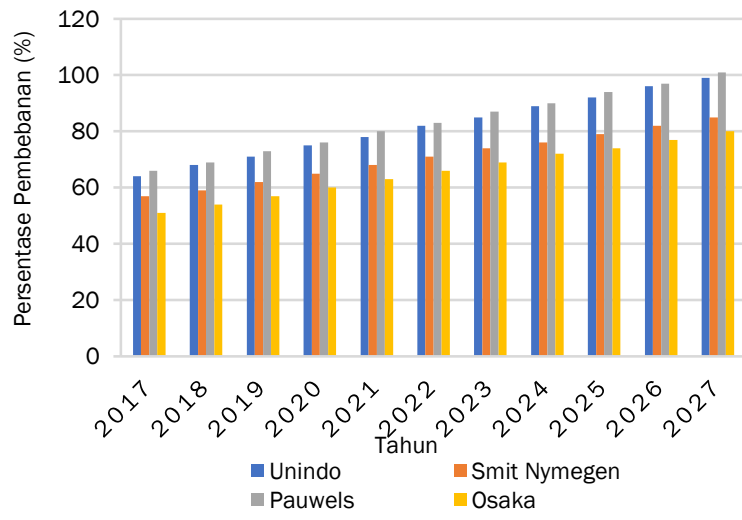

Gambar 10 Grafik Persentase Pembebanan Transformator GI Buduran Tahun 2017 s.d 2027

Berdasarkan tabel 17 dan Gambar 10 transformator II overload pada tahun 2022 dengan persentase pembenanan $82 \%$ dari kapasitas terpasang, transformator III overload pada tahun 
2026 dengan persentase pembenanan 82\% dari kapasitas terpasang, transformator IV overload pada tahun 2021 dengan persentase pembenanan $80 \%$ dari kapasitas terpasang, dan transformator $\mathrm{V}$ overload pada tahun 2027 dengan persentase pembenanan $80 \%$ dari kapasitas terpasang.

\section{Kesimpulan}

Berdasarkan hasil dari penelitian, korelasi antara pertumbuhan beban listrik golongan pelanggan Gardu Induk (GI) Buduran dengan sektor perekonomian pada data Produk Domestik Regional Bruto (PDRB) masing-masing sektor golongan pelanggan berkolerasi sangat kuat dan signifikan

Prakiraan beban tahun 2017 sampai 2027 per-golongan pelanggan GI Buduran diperkirakan akan terus naik pada setiap sektornya. Beban pergolongan pelanggan tersebut akan mempenguruhi pertumbuhan beban pada transformator di GI Buduran, dimana diestimasikan beban masingmasing transformator pada tahun 2017 sampai 2027 juga mengalami kenaikan, dengan akurasi estimasi menggunakan MAPE dalam kategori re Reasonable (Layak).

Berdasarkan hasil estimasi beban tranformator, Kondisi kapasitas transformator GI Buduran akan mengalami overload pada rentan tahun 2017 s.d 2027, dimana pada transformator II overload pada tahun 2022, transformator III overload pada tahun 2026, transformator IV overload pada tahun 2021, dan transformator $\mathrm{V}$ overload pada tahun 2027 dengan beban mencapai 16,1 MVA (80\%) dari kapasitas terpasang.

\section{Daftar Pustaka}

[1] Badan Pusat Statistik (BPS) Kabupaten Sidoarjo. .Kabupaten Sidoarjo Dalam Angka 2017. Sidoarjo: Badan Pusat Statistik (BPS) Kabupaten Sidiorajo, 2017

[2] Suswanto, D. Sistem Distribusi Tenaga Listrik untuk Mahasiswa Elektro, Edisi pertama. Padang: Universitas Negeri Padang, 2007

[3] H.L.Willis, "Spatial Electric Load Forecasting: Spatial Load Forecasting in Developing Economies," in Marcel Dekker Inc, pp. 631671, 2002.

[4] PLN. SPLN 17:1979 Pedoman Pembebanan Transformator Terendam Minyak. Jakarta: PLN, 1979

[5] M. Ferry, Sukma D.Y, dan Ervianto E. "Analisis Keberadaan dan Pengembangan Gardu Induk Distribusi $20 \mathrm{Kv}$ di Kota Pekanbaru" jom FTEKNIK vol. 2 no. 2, Oktober 2015
[6] Amral. N, Özveren. C, And King. D, "Short Term Load Forecasting using Multiple Linear Regression", UPEC - 1192, 2007

[7] M. Syarifruddin, Lukmal. H Dikpride. D, “Metode Regresi Linier Untuk Prediksi Kebutuhan Energi Listrik Jangka Panjang (Studi Kasus Provinsi Lampung)", Jurnal Informatika dan Teknik Elektro Terapan, Vol: 1 (No. 2), 2014:http://garuda.ristekdikti.go.id/journal/ar ticle/329982

[8] Jay, H.,\& Render, B. Manajemen Operasi. Jakarta: Selemba Empat, 2010

[9] Harring, Jeffrey R. and Wasko, John A., "Probabilistic Inferences for the Sample Pearson Product Moment Correlation," Journal of Modern Applied Statistical Methods, vol. 10, Iss. 2, Article 8, 2011.

[10]Kurz A.K. and Mayo. S.T. Statistical Method in Education and Psychology. Springer Science \& Business, LLC. Verlag-Berlin Heidelberg, New York, 1979

[11]Sugiyono. Statistika untuk Penelitian Cetakan Keduabelas. Bandung : Alfabeta, 2000

[12]Vanajakshi, L., \& Rilett, I. R. A Comparison Of The Performance of Artificial Neural Network And Support Vector Machines For The Prediction Of Traffic Speed. IIEEE Intelligent Vehicles Symposium, pp. 194-199, 2004

[13]Yuan O, A.N. Afandi, H. Putranto, "Power Demand Forecasting Considering Actual Peak Load Using Artificial Neural Network," in 2018 $5^{\text {th }}$ International Conference on Electrical Engineering, Computer Science, and Informatics (ICEECSI), 2018.

[14]Gustriansyah, R. 2017. Analisis Metode Single Exponential Smoothing dengan Brown Exponential Smoothing pada Studi Kasus Memprediksi Kuantitif Penjualan Produk Farmasi di Apotek. Seminar Nasional Teknologi Informasi dan Multimedia 2017. Dari http://researchgate.net/publication/3142375 2

[15]Bawan,E.K. “Estimasi Pembebanan Trasformator Gardu Induk 150 KV", Jurnal IImiah Foristek, Vol: 3 (No. 2), 289-293. 2014 http://jurnal.untad.ac.id/jurnal/index.php/FO RISTEK/article/view/1618/1072 